\title{
0 KONIECZNOŚCI I MOŻLIWOŚCIACH ZAPEWNIENIA OSOBOM NIEPEENOSPRAWNYCH DOSTĘPU DO ZABYTKOWYCH OBIEKTÓW UŻYTECZNOŚCI PUBLICZNEJ
}

RYMSZA Barbara ${ }^{1}$ KAPERCZAK Krzysztof ${ }^{2}$ KILIAN-WALERZAK Justyna ${ }^{3}$

${ }^{1}$ prof. IBDiM dr hab. inż. Barbara Rymsza, Instytut Badawczy Dróg i Mostów, Warszawa https://orcid.org/0000-0002-0504-2360

${ }^{2}$ dr inż. Krzysztof Kaperczak, Instytut Badawczy Dróg i Mostów, Warszawa

https://orcid.org/0000-0001-9316-7712

${ }^{3}$ mgr Justyna Małgorzata Kiljan-Walerzak, Instytut Badawczy Dróg i Mostów, Warszawa https://orcid.org/0000-0002-8290-3005

ABSTRAKT: Niniejsza publikacja jest poświęcona problemowi zapewnienia dostępu do zabytkowych obiektów użyteczności publicznej osobom niepełnosprawnym, przy czym tę dostępność należy dostosować do potrzeb i możliwości tych osób niepełnosprawnych. Na przykładach pokazano, w jaki sposób można zapewnić dojście i dojazd do zabytkowych obiektów osobom niepełnosprawnym. Przedstawiono także możliwość wykorzystania wyników pracy doktorskiej dotyczących pochylni nowego typu (tymczasowej pochylniLPZ) charakteryzującej się większą „elastycznością” wzastosowaniu.

SŁOWA KLUCZE: Obiekty zabytkowe, dostępność, niepełnosprawni 


\section{Wprowadzenie}

Ze względu na obowiązujące zapisy prawne $\mathrm{w}$ zakresie ustawodawstwa ogólnego ${ }^{1,2,3}$ kształtowanie przestrzeni publicznej wymaga zastosowania projektowania uniwersalnego. Sprawia ono, że przestrzeń ta staje się dostępna dla wszystkich, w tym także osób z ograniczonymi możliwościami ruchowymi (np. osób niepełnosprawnych, starszych) i to w taki sposób, by mogli z niej korzystać wszyscy ludzie, w możliwie szerokim zakresie, bez potrzeby jej adaptacji lub specjalnego dostosowywania ${ }^{4}$.

O ile łatwo jest stosować powyższe zasady w projektowaniu obiektów nowobudowanych to znacznie trudniej w odniesieniu do już istniejących. Szczególnie trudny problem powstaje przy próbie adaptacji zabytkowych obiektów użyteczności publicznej do współczesnych wymogów osób zwiedzających. Należy pogodzić zasady projektowania uniwersalnego z wymaganiami konserwatorskimi np. w zakresie stosowanych materiałów lub w odniesieniu do przeróbek mogących zmienić np. bryłę obiektu.

$\mathrm{Z}$ dotychczasowych doświadczeń w zakresie zapewnienia dostępności obiektów zabytkowych wynika, że działania dostosowawcze nie zawsze są przeprowadzane oraz często są niewystarczające i nie zadowalają niepełnosprawnego użytkownika. A jest to znaczna liczba osób, która w wyniku niekorzystnych procesów demograficznych stale się zwiększa. Zwłaszcza, że według Komisji Europejskiej ${ }^{5}$ do kategorii osób niepełnosprawnych (często zwanych PRM $\mathrm{z}$ ang. People with Reduced Mobility - osoby o ograniczonej możliwości poruszania się) zalicza się m.in. osoby:

- na wózkach inwalidzkich,

- niewidome i niedowidzące,

- z dziećmi, z ciężkim lub nieporęcznym bagażem, starsze, w ciąży,

- z upośledzeniem w zakresie komunikacji ( $w$ tym np. obcokrajowcy nie znający języka polskiego).

Liczba osób ON (Osoby Niepełnosprawne lub Osoby z Niepełnosprawnościami) w Polsce podczas spisu ludności ${ }^{6} \mathrm{w} 2011 \mathrm{r}$. została oszacowana na 12,2\% ludności tj. 4,7 mln obywateli. Natomiast z pracy naukowej K. Jaranowskiej ${ }^{7}$ wynika, że łączna liczba osób niepełnosprawnych powinna być co najmniej podwojona do nawet ok. $32 \%$.

Należy również wspomnieć, że dla osób ON, w ramach różnego typu projektów aktywizujących, są organizowane wycieczki do miejsc o szczególnych walorach edukacyjno-turystycznych, a takimi są różnego rodzaju obiekty zabytkowe. Dostosowując dojście do nich można znacząco zwiększyć liczbę osób zwiedzających obiekty zabytkowe.

Konstytucja Rzeczpospolitej Polskiej z dnia 2 kwietnia 1997 r.

Karta Praw Osób Niepełnosprawnych - Uchwała Sejmu Rzeczypospolitej Polskiej z dnia 1 sierpnia 1997 r.

Konwencja ONZ z dnia 13 grudnia 2006 r.

https://pl.wikipedia.org/wiki/Projektowanie_uniwersalne.

People with Reduced Mobility. Decyzja nr 2008/164/WE z 2007 r.

Narodowy Spis Powszechny Ludności i Mieszkań z 2011 r.

Osoby niepetnosprawne w środowisku miejskim. COBO-PROFIL, Warszawa, 1996. 
Zapewnienie osobom niepełnosprawnym dostępu do zabytkowych obiektów użyteczności publicznej jest zagadnieniem bardzo ważnym $\mathrm{z}$ punktu widzenia liczby potencjalnych zwiedzających i wymaga wiedzy specjalistycznej, odmiennej od typowych zagadnień opieki nad zabytkami.

Zakres adresatów „podpowiedzi” zawartych w tej pracy jest ogromny, a specyfika tematu sprawia, że przybliżenie problematyki dostępu do zabytkowych obiektów użyteczności publicznej zasługuje na uwagę także ze strony specjalistów od konserwacji i prezentacji dorobku dziedzictwa kulturowego.

\section{Problem dostępności przestrzeni publicznej dla osób zograniczonymi możliwościami ruchowymi}

Osoby $\mathrm{z}$ niepełnosprawnością mogą się charakteryzować różnorodnymi rodzajami niepełnosprawności, która może występować w różnym stopniu, a co istotne, może być także zróżnicowana zdolność jej przezwyciężania przez poszczególne osoby.

$\mathrm{Z}$ jakim rezultatem zakończy się próba pokonania trudności zależy od indywidualnych możliwości psycho-fizyczych poszczególnych osób, w tym właściwej rehabilitacji umożliwiającej tworzenie umiejętności przystosowania się i rekompensowania deficytów.

Chcąc zapewnić sprawne, a co ważne, bezpieczne poruszanie się osób ON w przestrzeni publicznej, projektanci powinni poznać rodzaje przeszkód i niebezpieczeństw, z jakimi zmagają się osoby niepełnosprawne chcące poruszać się samodzielnie. Przeszkody te nie są jednakowe dla wszystkich, zależą od rodzaju niepełnosprawności. I tak, są to, dla:

- osób niesprawnych ruchowo:

- różnice poziomów, pojedyncze stopnie, schody, strome pochylnie lub ich brak, niewłaściwa wysokość poręczy lub ich brak - generujące brak możliwości przemieszczania się lub groźbę upadku,

- wąskie przejścia - brak możliwości przemieszczania się;

- osób słabo słyszących i głuchych:

- komunikaty podawane tylko werbalnie lub pisemnie, ale skomplikowanym językiem polskim - brak zrozumienia znaczenia komunikatu,

- brak pętli indukcyjnej - problem z odbiorem dźwięku przez aparat słuchowy;

- dla osób niewidomych i słabowidzących:

- brak oznakowania (nie zasygnalizowane) zmianą faktury nawierzchni lub niewyróżnione kolorami kontrastowymi różnice poziomów, krawędzie: stopni, progów, pochylni - możliwość upadku,

- elementy infrastruktury technicznej zawieszone w obrębie skrajni drogi - możliwość urazu głowy,

- polerowane powierzchnie - możliwość wystąpienia zjawiska olśnienia,

- przezroczyste szyby, ściany, lustra - możliwość urazu głowy, utrata orientacji, 
- informacje podawane wyłącznie w formie wyświetlanej (nie głosowej), małymi literami i nie alfabetem Braille'a - dezorientacja.

Przepisy techniczno-budowlane ${ }^{8,9,10,11,12,13}$ w różnym stopniu i zakresie definiują wymagania budowlane gwarantujące dostosowanie środowiska człowieka do potrzeb osób niepełnosprawnych.

Jednocześnie trzeba zaznaczyć, że np. w ustawie o ochronie zabytków i opiece nad zabytkami ${ }^{14}$ nie ma nawet wzmianki o dostępności. W przepisach tych nie umieszczono przykładowych schematów zapewnienia dostępności. Pozostawiono spory margines swobody dla projektanta, aby mógł wybrać rozwiązania optymalne do danego przypadku w zależności od specyfiki obiektu i miejsca. Tak, aby wesprzeć a nie ograniczać jego inwencję i kreatywność oraz umiejętności i wiedzę wsparte osiągnięciami nauki i techniki. Dzięki temu wytworzył się naturalny proces poszukiwania i kreowania szerokiej gamy rozwiązań w zależności od potrzeb i możliwości danego miejsca i obiektu. W ten sposób powstało wiele prawidłowo dostosowanych obiektów, ale także wiele rozwiązań złych - niezapewniających wymaganej dostępności. Przyczyn tych niepowodzeń można się doszukiwać w braku doświadczenia i niewiedzy projektantów, zarządców, nadzoru konserwatorskiego a także w nadmiernym pośpiechu, oszczędnościach finansowych, niekiedy w pomyłkach i niedbalstwie, ale także w interpretacji zapisów prawa.

Wiele zasad związanych z rozwiązywaniem problemu dostępności przestrzeni publicznej jest zawartych w dokumentach, które są aktami prawa miejscowego ${ }^{15,16,17}$. Zebrane w nich wymagania lub zalecenia postanowiono wprowadzić do stosowania przy wykonywaniu wszystkich inwestycji miejskich (publicznych), jako „standardy dostępności”. Przykładem mogą być „Standardy dostępności dla Miasta Stołecznego Warszawy”, których wstępną wersję na zlecenie Biura Pomocy i Projektów Społecznych Urzędu m.st. Warszawy opracowano w IBDiM ${ }^{18}$.

8 Ustawa z dnia 7 lipca 1994 r. - Prawo budowlane Dz.U. 1994 nr 89 poz. 414 z pozn. zm.

9 Ustawa z dnia 27 marca 2003 r. o planowaniu i zagospodarowaniu przestrzennym Dz.U. $2003 \mathrm{nr} 80$ poz. 717 z pozn. zm.

10 Rozporządzenie Ministra Infrastruktury z dnia 12 kwietnia 2002 r. w sprawie warunków technicznych, jakim powinny odpowiadać budynki i ich usytuowanie Dz.U. $2002 \mathrm{nr} 75$ poz. 690 z pozn. zm.

${ }_{11}$ Rozporządzenie Ministra Transportu i Gospodarki Morskiej z dnia 30 maja 2000 r. w sprawie warunków technicznych, jakim powinny odpowiadać drogowe obiekty inżynierskie i ich usytuowanie Dz.U. $2000 \mathrm{nr} 63$ poz. $735 \mathrm{z}$ pozn. zm.

12 Rozporządzenie Ministra Transportu i Gospodarki Morskiej z dnia 2 marca 1999 r. Dz.U. 1999 nr 43 poz. $430 \mathrm{z}$ pozn. $\mathrm{zm}$.

13 Normy dźwigowe PN-EN 81-70:2005 i PN-EN 81-40:2008.

14 Ustawa z dnia 23 lipca 2003 r. o ochronie zabytków i opiece nad zabytkami Dz.U. 2003 nr 162 poz. 1568.

15 Zarządzenie Nr 10740/13/VI/U Prezydenta Miasta Gdyni dotyczące wprowadzenia do stosowania standardów dostępności dla miasta Gdyni.

16 Zarządzenie nr 247/2008/P Prezydenta Poznania w sprawie wymogów, jakim powinny odpowiadać przejścia dla pieszych, przejścia podziemne, przejścia nadziemne, przystanki komunikacji publicznej i chodniki.

17 Zarządzenie nr 1539/2016 Prezydenta miasta stołecznego Warszawy z dnia 12.10.2016 r. w sprawie tworzenia korzystnych warunków dla ruchu pieszego na terenie miasta stołecznego Warszawy.

18 Rymsza B., Kaperczak K., Standardy dostępności dla Miasta Stołecznego Warszawy, maszynopis opracowany na zlecenie Biura Pomocy i Projektów Społecznych Urzędu m.st. Warszawy. Warszawa, 2015, s. 98. 


\section{Trudności i sposoby zapewnienia dostępu do obiektów zabytkowych}

Dla osób z ograniczonymi możliwościami poruszania się szczególnie istotny jest bliski (jak najbliższy) dojazd do obiektu. Zazwyczaj osoby te poruszają się albo samochodem osobowym, podjeżdżając i parkując samochód w bezpośredniej bliskości obiektu, albo autokarem, który na chwilę zatrzymuje się na jezdni w okolicy obiektu, aby umożliwić najpierw wysiadanie a po skończonym zwiedzaniu wsiadanie takich osób.

Miejsca specjalnie przeznaczone na parkowanie pojazdów takich osób - tzw. "koperty", powinny charakteryzować się specjalnymi parametrami (większa szerokość, gładka nawierzchnia - Ryc. 1.), zazwyczaj sytuuje się je możliwie blisko wejść do obiektów. Dodatkowo dojście od „kopert” do obiektu należy odpowiednio przystosować (stosując gładką i utwardzoną nawierzchnię, obniżone krawężniki).
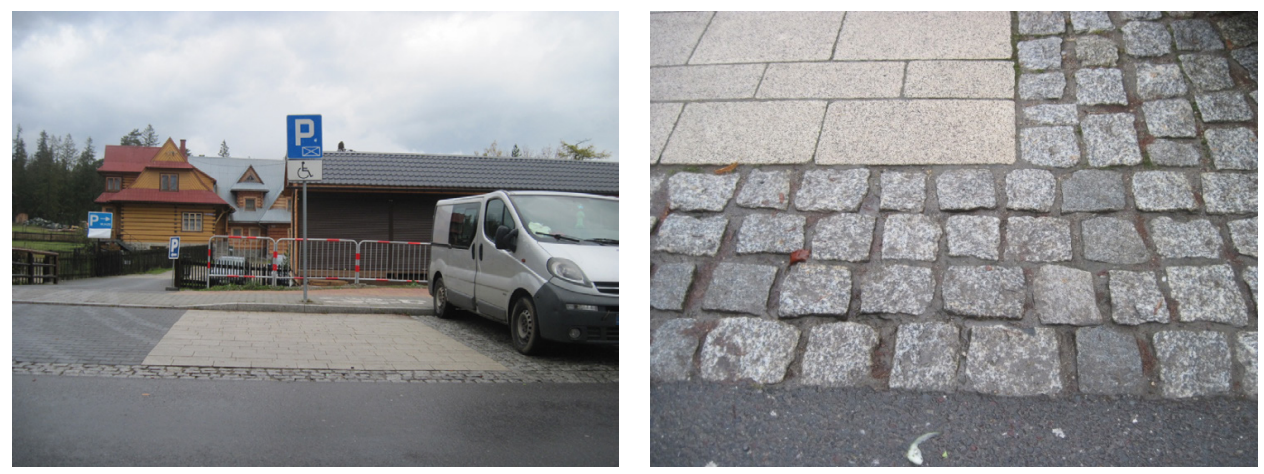

Ryc. 1 Przykład parkingu o nawierzchni z kamienia łupanego, gdzie na części przeznaczonej dla parkowania osoby niepełnosprawnej ułożono nawierzchnię gładką (fot. autor)

Często problemem w pokonaniu drogi od pojazdu do obiektu staje się przestrzeń okalająca obiekty zabytkowe - nawierzchnie dróg i chodników oraz elementy małej architektury przeszkadzające w poruszaniu się. Nawierzchnie te są często kamienne z kostki łupanej lub rzędowej, są nierówne i śliskie zwłaszcza w czasie wilgotnej pogody, sprawiając wiele kłopotów osobom na wózkach inwalidzkich i z kulami. Rozwiązaniem jest nadanie albo całości albo przynajmniej części z nich, gładkiej powierzchni. Na Ryc. 2 pokazano jak niewielka różnica w powierzchni nawierzchni może decydować o spełnieniu lub nie warunku dostępności. 

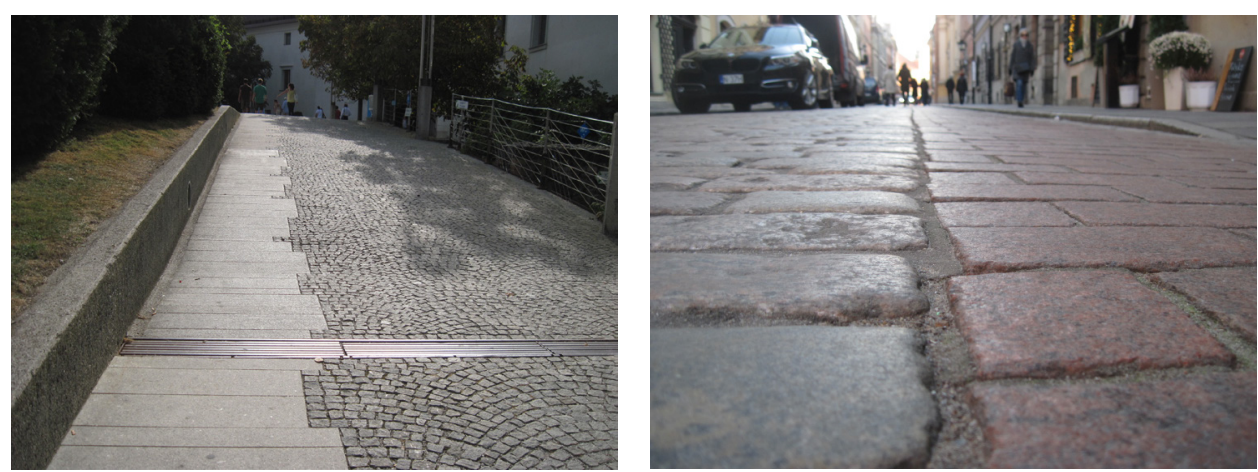

Ryc. 2 Przykład nawierzchni dojścia do obiektu zabytkowego, część powierzchni jest gładka lub obok powierzchni obłej jest płaska (fot. autor)

Do absolutnej większości obiektów zabytkowych wejście prowadzi po schodach, są to przynajmniej jeden, dwa a nawet więcej stopni.

Najlepszym rozwiązaniem jest dopasowanie całości przestrzeni do poziomu wejścia podniesienie w sposób łagodny większej części przylegającego chodnika, bądź wybudowanie pochylni niwelującej kilkudziesięciocentymetrową różnicę wysokości.

Dobudowanie pochylni może być utrudnione ze względu na ingerencję w bryłę budynku. Odpowiedzią może być wybudowanie pochylni nawiązujących swą konstrukcją do zabytkowego charakteru budynku oraz otoczenia (Ryc. 3). Jeśli nie jest to możliwe pochylnie wykonuje się, jako elementy przenośne - niepołączone na stałe z obiektem, które nie zmieniają bryły budynku chociaż zmieniają ich estetykę. Wykonane są zazwyczaj ze stali, aluminium, czasem z drewna.
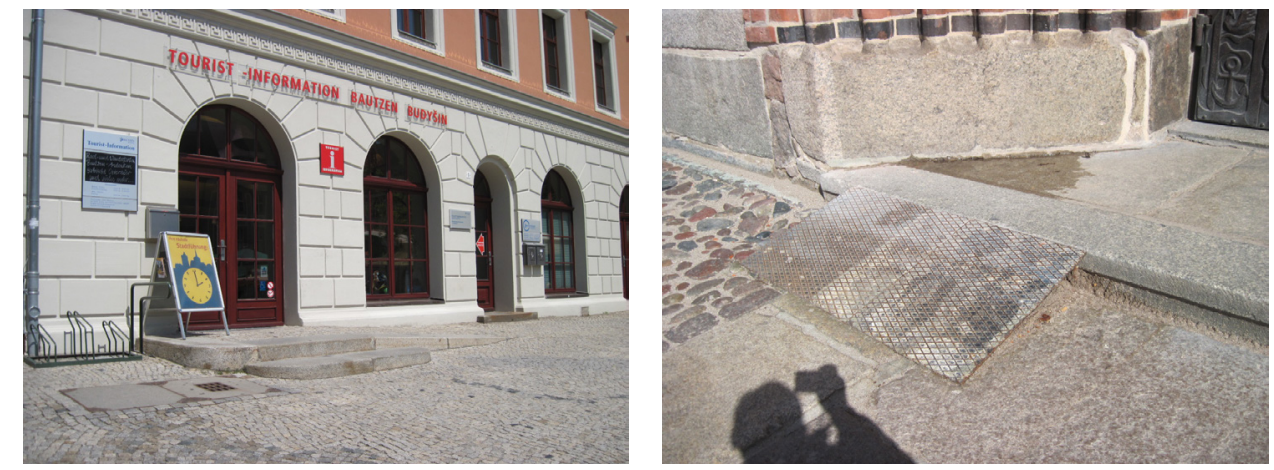

Ryc. 3 Pochylnia wkomponowana w otoczenie obiektu zabytkowego oraz tymczasowa pochylnia stalowa (fot. autor)

Niekiedy jedynym rozwiązaniem staje się montaż urządzenia dźwigowego (np. podnośnika pionowego lub dźwigu osobowego). Zaletą urządzeń dźwigowych jest ich estetyczna konstrukcja oraz zastosowane materiały - zazwyczaj szkło i stal (Ryc. 4). 

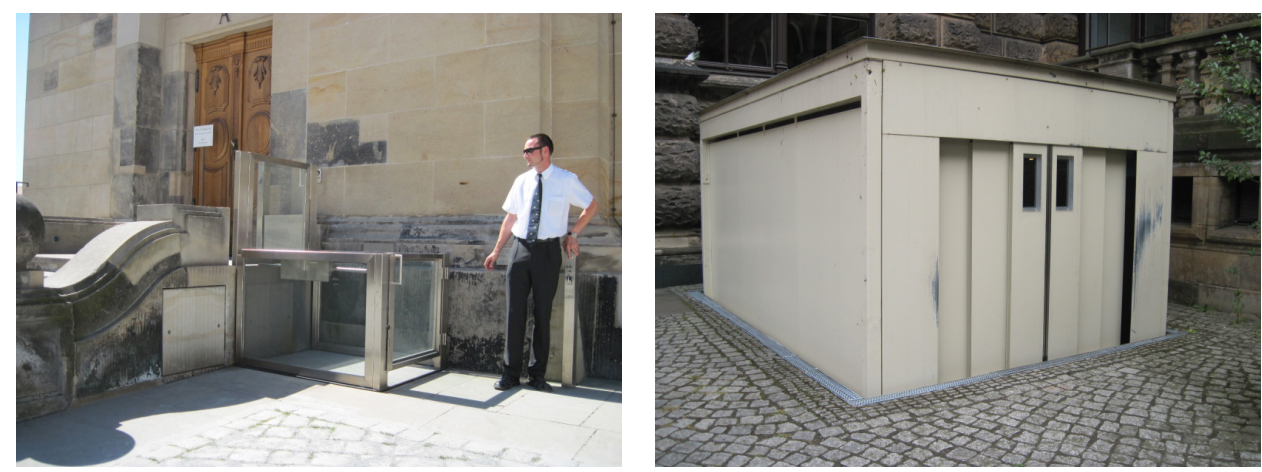

Ryc. 4 Przykłady popularnego podnośnika pionowego montowanego przy obiektach zabytkowych oraz podziemnego dźwigu osobowego (fot. autor)

Urządzenia dźwigowe, jako urządzenia mechaniczno-elektryczno-elektroniczne, są bardzo wrażliwe na zmiany temperatury, opady atmosferyczne, akty wandalizmu (uderzenia mechaniczne, wlewanie płynów, podpalanie) oraz nieprawidłową eksploatację. Z tego powodu często są niesprawne. Niezawodna jest prawie zawsze pochylnia, lecz co zrobić jeżeli w przestrzeni publicznej i obszarze zabytkowym:

- wybudowanie pochylni „klasycznej” w warunkach silnie zurbanizowanej przestrzeni miejskiej nie zawsze jest możliwe (np. brakuje wolnego terenu, obecność podziemnej infrastruktury technicznej utrudnia posadowienie fundamentów pochylni, nastąpi pogorszenie estetyki obiektu i jego otoczenia);

- zastosowanie urządzenia dźwigowego z powodu jego awaryjności nie jest akceptowane przez ON.

Taka sytuacja skłania do próby zastosowania pochylni tymczasowej o zmienionych („ostrzejszych”) parametrach, którą można byłoby w wielu miejscach zastosować. Wystarczającym uzasadnieniem do zastosowania byłby tymczasowy charakter pochylni - jej funkcjonowanie do czasu wykonania rozwiązania docelowego, czyli zbudowania pochylni „klasycznej” lub montażu niezawodnego urządzenia dźwigowego.

\section{Lekka Pochylnia Zastępcza (LPZ)}

Idea poszukiwania nowego typu pochylni o zmienionych parametrach technicznych, które pozwolą na jej stosowanie $w$ trudnych warunkach terenowych, to efekt wieloletnich prac naukowo-badawczych prowadzonych w IBDiM początkowo przez śp. mgr. inż. Michała Czerniaka a uwieńczonych pracą doktorską Krzysztofa Kaperczaka pt. „Propozycja poprawy dotychczasowych rozwiązań w zakresie dostępności obiektów inżynierskich dla osób niepełnosprawnych" ${ }^{19}$. W pracy tej można znaleźć także wiele podpowiedzi dotyczących różnego

19 Kaperczak K., Rozprawa doktorska „Propozycja poprawy dotychczasowych rozwiazań w zakresie dostępności obiektów inżynierskich dla osób niepełnosprawnych" Wydawnictwa Uniwersytetu TechnologicznoPrzyrodniczego im. Jana i Jędrzeja Śniadeckich w Bydgoszczy. 2017, s. 202. Promotorem pracy była prof. B. Rymsza 


\section{Barbara Rymsza, Krzysztof Kaperczak, Justyna Kilian-Walerzak}

rodzaju rozwiązań jakie należy stosować w wypadku dostosowywania przestrzeni publicznej do potrzeb osób niepełnosprawnych.

Kwerenda literatury fachowej oraz przepisów krajowych i zagranicznych pozwoliła na sformułowanie propozycji innowacyjnych parametrów pochylni. Zbudowano prototyp pochylni LPZ i przeprowadzono badania testowe z udziałem wybranej grupy osób (z różnym stopniem sprawności) poruszających się na wózkach inwalidzkich (Ryc. 5).

Uzyskano potwierdzenie akceptacji przez te osoby idei pochylni LPZ oraz przyjętych jej parametrów. Zatem taką pochylnię tymczasową można stosować z zastrzeżeniem jednak, że powinna ona być montowana tylko w wyjątkowych sytuacjach (jako rozwiązanie zastępcze), stąd nazwa LPZ - Lekka Pochylnia Zastępcza.

Niżej podano parametry pochylni LPZ odnosząc je do parametrów pochylni klasycznej (podane w nawiasach):

- zwiększono pochylenie do $\mathrm{p}=13 \%$ (z 8 lub 10\%),

- zastosowano jedną parę poręczy na wysokości pośredniej $\mathrm{h}=0,85 \mathrm{~m}$ (zamiast dwóch na wysokościach 0,75 i $0,90 \mathrm{~m}$ ),

- zawężono prześwit między poręczami $\mathrm{b}=0,90 \mathrm{~m}$ (zamiast 1,00 m),

- zastosowano poręcz pojedynczą i o średnicy zmniejszonej do $\mathrm{d}=35 \mathrm{~mm}$ (zamiast $60 \mathrm{~mm}$ ),

- zastosowano nawierzchnię ażurową z blachy perforowanej lub $\mathrm{z}$ krat pomostowych (zamiast nawierzchni pełnej bez otworów),

- wprowadzono konieczność oznakowania pochylni symbolem zalecenia potrzeby wsparcia osoby ON przez osobę chodzącą (brak potrzeby oznakowywania).
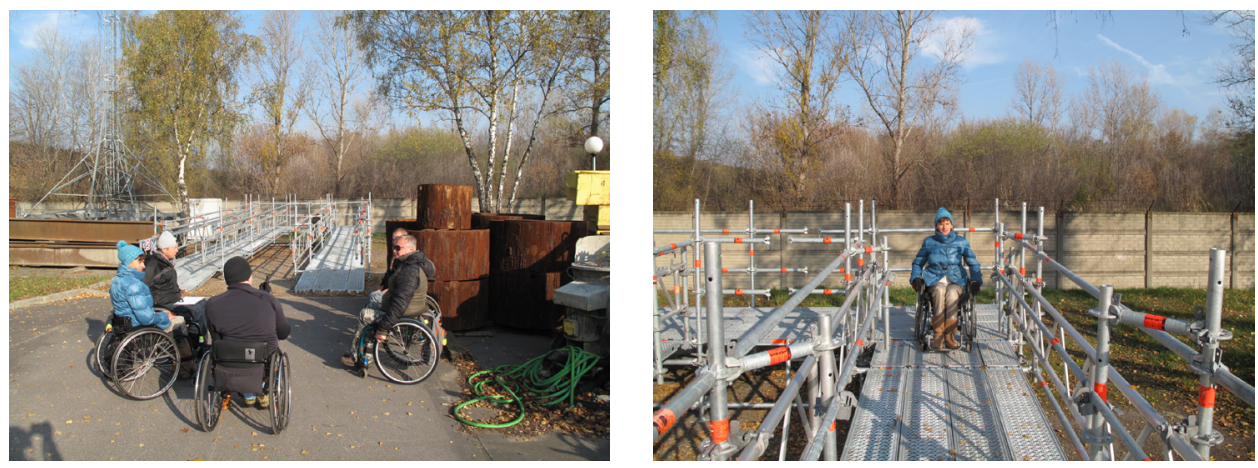

Ryc. 5 Testy Lekkiej Pochylni Zastępczej (LPZ) (fot. autor)

Pochylnia LPZ dzięki większemu pochyleniu, mniejszej masie oraz tymczasowemu charakterowi może być wykorzystywana do zapewniania dostępności do zabytkowej przestrzeni oraz zabytkowych obiektów.

Wariant rozbudowany pochylni to Klatkowa Lekka Pochylnia Zastępcza (KLPZ), czyli układ klatkowy pochylni ze spocznikami, który umożliwia pokonywanie większych różnic wysokości. 


\section{Podsumowanie}

Umożliwienie osobom niepełnosprawnym dostępu do obiektów zabytkowych, rozumianego jako dojazd lub dojście do obiektu, to pierwszy krok na drodze do pełnej prezentacji walorów tych obiektów. Przykłady zastosowania rozwiązań poprawiających dostępność do obiektów użyteczności publicznej zostały zaprezentowane także w publikacji ${ }^{20}$ dotyczącej np. zamkowych wież widokowych oraz $\mathrm{w}$ artykule ${ }^{21} \mathrm{w}$ odniesieniu do tzw. pochylni wewnątrzschodowych.

Osobnym problemem jest dostosowanie wnętrz obiektów do potrzeb i możliwości osób ON, ale jest to szeroki temat do kolejnego artykułu.

Ważne jest, aby dostrzec i zrozumieć bariery jakie muszą pokonywać osoby ze specjalnymi potrzebami, a tych jest wokół nas coraz więcej.

\footnotetext{
20 Kaperczak K., Rymsza B., Wieże widokowe - podwójny problem z integracją; [w:] Integracja sztuki i techniki $w$ architekturze $i$ urbanistyce, Wydawnictwa Uczelniane Uniwersytetu Technologiczno-Przyrodniczego w Bydgoszczy, t. IV/I s. 101-108 (s. 150), nr ISBN 978-83-65603-15-9.

${ }^{21}$ Kaperczak K., Rymsza B., Pochylnia wewnątrzschodowa. Materiały Budowlane, nr 7/2018 s. 48, ISSN 01372971, e-ISSN 2449-951X.
} 


\section{Bibliografia}

Kaperczak K., Rozprawa doktorska „Propozycja poprawy dotychczasowych rozwiązań w zakresie dostępności obiektów inżynierskich dla osób niepetnosprawnych" Wydawnictwa Uniwersytetu Technologiczno-Przyrodniczego im. Jana i Jędrzeja Śniadeckich w Bydgoszczy. 2017, s. 202. Promotorem pracy była prof. B. Rymsza.

Kaperczak K., Rymsza B., Pochylnia wewnątrzschodowa. Materiaty Budowlane, nr 7/2018 s. 48, ISSN 0137-2971, e-ISSN 2449-951X.

Kaperczak K., Rymsza B., Wieże widokowe - podwójny problem z integracja, [w:] Integracja sztuki i techniki $\mathrm{w}$ architekturze i urbanistyce, Wydawnictwa Uczelniane Uniwersytetu Technologiczno-Przyrodniczego w Bydgoszczy, t. IV/I s. 101-108 (ss. 150), nr ISBN 978-8365603-15-9.

Karta Praw Osób Niepełnosprawnych - Uchwała Sejmu Rzeczypospolitej Polskiej z dnia 1 sierpnia $1997 \mathrm{r}$.

Konstytucja Rzeczpospolitej Polskiej z dnia 2 kwietnia 1997 r.

Konwencja ONZ z dnia 13 grudnia 2006 r.

Narodowy Spis Powszechny Ludności i Mieszkań z 2011 r.

Normy dźwigowe PN-EN 81-70:2005 i PN-EN 81-40:2008.

Osoby niepełnosprawne w środowisku miejskim. COBO-PROFIL, Warszawa $1996 \mathrm{r}$.

People with Reduced Mobility. Decyzja nr 2008/164/WE z 2007 r.

Rozporządzenie Ministra Infrastruktury z dnia 12 kwietnia $2002 \mathrm{r}$. w sprawie warunków technicznych, jakim powinny odpowiadać budynki i ich usytuowanie Dz.U. $2002 \mathrm{nr} 75$ poz. 690 z pozn. zm.

Rozporządzenie Ministra Transportu i Gospodarki Morskiej z dnia 30 maja 2000 r. w sprawie warunków technicznych, jakim powinny odpowiadać drogowe obiekty inżynierskie i ich usytuowanie Dz.U. $2000 \mathrm{nr} 63$ poz. 735 z pozn. zm.

Rozporządzenie Ministra Transportu i Gospodarki Morskiej z dnia 2 marca 1999 r. Dz.U. 1999 nr 43 poz. $430 \mathrm{z}$ pozn. zm.

Rymsza B., Kaperczak K., Standardy dostępności dla Miasta Stołecznego Warszawy, maszynopis opracowany na zlecenie Biura Pomocy i Projektów Społecznych Urzędu m.st. Warszawy. Warszawa, 2015, s. 98.

Ustawa z dnia 7 lipca 1994 r. - Prawo budowlane Dz.U. 1994 nr 89 poz. 414 z pozn. zm.

Ustawa z dnia 23 lipca 2003 r. o ochronie zabytków i opiece nad zabytkami Dz.U. 2003 nr 162 poz. 1568.

Ustawa z dnia 27 marca 2003 r. o planowaniu i zagospodarowaniu przestrzennym Dz.U. 2003 nr 80 poz. 717 z pozn. $z m$.

Zarządzenie Nr 10740/13/VI/U Prezydenta Miasta Gdyni dotyczące wprowadzenia do stosowania standardów dostępności dla miasta Gdyni. 
Zarządzenie nr 1539/2016 Prezydenta miasta stołecznego Warszawy z dnia 12.10.2016 r. w sprawie tworzenia korzystnych warunków dla ruchu pieszego na terenie miasta stołecznego Warszawy.

Zarządzenie nr 247/2008/P Prezydenta Poznania w sprawie wymogów, jakim powinny odpowiadać przejścia dla pieszych, przejścia podziemne, przejścia nadziemne, przystanki komunikacji publicznej i chodniki.

https://pl.wikipedia.org/wiki/Projektowanie_uniwersalne. 